документації; створення й використання бази даних співробітників та учнів; моніторинг діяльності вчителів; пошук і відбір інформації за допомогою Інтернету (від нормативноправової до купівлі підручників - можливості нині дуже широкі); оперативне управління навчальним закладом шляхом інтерактивних телеконференцій, віртуальних планерок, передавання термінової інформації на екрани учительських машин; налагоджування творчих зв'язків з іншими навчальними закладами, у тому числі за кордоном; використання електронної пошти для зв'язку, наприклад, з органами управління освітою; психологічне тестування працівників і дітей у процесі навчальної діяльності.

Застосування інформаційно-комунікаційних технологій у галузі освіти i безпосередньо в діяльності навчального закладу стало нагальною потребою сучасного суспільства. Упровадження інформаційно-комунікаційних технологій у навчально-виховний процес школи позитивно впливає на всі компоненти системи навчання: мету, зміст, методи й організаційні форми навчання, засоби навчання та забезпечить поступовий перехід освіти на новий, якісний рівень. Це дозволяє розв'язувати складні й актуальні завданні педагогіки, що забезпечить розвиток інтелектуального, творчого потенціалу, аналітичного мислення педагогічних працівників та його самостійності.

Для запровадження інформаційних технологій щодо ефективної модернізації освіти треба здійснити оновлення технічного арсеналу засобів навчання шляхом оптимізації реалізації державних програм, що спрямовані на інформатизацію, комп'ютеризацію та оновлення матеріально-технічної бази шкіл, надання всім вільного доступу до мережі Інтернет.

Підготовка керівників до сучасного управління школою за допомогою IКТ є дієвим складником ефективного освітнього менеджменту.

\title{
Література
}

1. Даниленко Л. І. Оновлення змісту та організаційної структури навчання керівних кадрів в інституті підвищення кваліфікації / Л. І. Даниленко // Директор школи. - 2000. № 18. - С. 1-2. 2. Інструментарій менеджера освіти. Сайт творчої групи Єльнікових [Електронний ресурс]/ Режим доступу: www.elnik.kiev.ua 3. Карамушка Л. М. Психологічні основи управління у системі середньої освіти : [навч. посібник]/

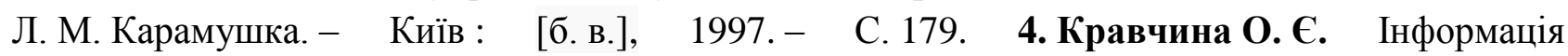
організаційно-управлінської діяльності в загальноосвітній школі [Електронний ресурс]/ О. С. Кравчина // Інформаційні технології і засоби навчання. - 2008. - № 3 (7). - Режим доступу до журн. : http:www.ime.edu-net/em_7/emg.html 5. Національна доктрина розвитку освіти у ХХІ столітті // Освіта України. - 2001. - № 1. - С. 22-25. 6. Тоффлер Е. Третя хвиля / Е. Тоффлер. - Київ : Вид. дім «Всесвіт», 2000. - 480 с. 7. Травін В. І. Про стилі та методи керівництва / В. І. Травін // Директор школи. Україна. - 2009. - № 9 (115). - С. 66-72.

УДК 378: [373.2:316.647.5]

Валентина Ляпунова

\section{БАЗОВІ ПОЛОЖЕННЯ КОНЦЕПЦІЇ ПІДГОТОВКИ МАЙБУТНІХ ПЕДАГОГІВ ДО ФОРМУВАННЯ ТОЛЕРАНТНОСТІ В ДІТЕЙ СТАРШОГО ДОШКІЛЬНОГО ВІКУ}

Ляпунова В. А. Базові положення концепції підготовки майбутніх педагогів до формування толерантності в дітей старшого дошкільного віку.

У статті розглядаються базові положення концепції підготовки майбутніх вихователів 
дошкільних закладів до формування толерантності в дітей старшого дошкільного віку. Авторський підхід грунтується на засадах антропоцентричного розуміння взаємодії вихователя з дитиною, відкритості й діалогічності.

Ключові слова: фахова підготовка вихователя, формування толерантності, концептуальні положення, принципи та умови підготовки вихователя.

Ляпунова В. А. Базовые положения концепции подготовки будущих педагогов к формированию толерантности у детей старшего дошкольного возраста.

В статье рассматриваются базовые положения подготовки будущих воспитателей дошкольных учреждений к формированию толерантности у детей старшего дошкольного возраста. Авторский подход основывается на антропоцентристском понимании взаимодействия воспитателя с ребёнком, открытости и диалогичности.

Ключевые слова: профессиональная подготовка воспитателя, формирование толерантности, концептуальные положения, принципы и условия подготовки воспитателя.

Liapunova V. A. The basic essentials of the concept for training future teachers to the formation of tolerance in children of preschool age.

The article discusses the basic principles for taining future teachers of pre-school institutions to the formation of tolerance in children of preschool age. The author's approach is based on anthropocentric understanding of kindergartener interaction with the child as well as sociability and dialogueness.

Key words: professional training of a kindergartener, formation of tolerance, conceptual essentials, principles and conditions for training kindergarteners.

Актуальність проблеми виховання підростаючого покоління в дусі толерантності об'єктивно зумовлена змінами останніх років в економічному, політичному, культурному житті країни та світу. Епоха ізольованого існування держав відійшла в минуле, водночас зростаюча мобільність населення земної кулі перетворює багато країн на полікультурні співтовариства. В умовах полікультурного світу місце універсального принципу людської життєдіяльності поступово займає толерантність.

Підготовка до формування толерантності в дітей $є$ компонентом професійної підготовки педагогів, що забезпечує цілеспрямований і методично грамотний вплив на процес засвоєння дитиною норм толерантності задля формування толерантної поведінки i толерантної свідомості як необхідних умов соціалізації дитини. Вплив на розвиток толерантності дитини відбувається у всіх випадках педагогічного спілкування. Діти засвоюють моральні норми, зразки толерантної поведінки дорослого у процесі спілкування 3 ним. Це відбувається навіть тоді, коли сам педагог не ставить завдання розвитку толерантності дитини, коли він цілеспрямовано не впливає на толерантність, але вплив цей все одно здійснюється. Він може виявитися як позитивним, так і негативним. У зв'язку 3 цим, названий компонент повинен бути обов'язковим складником підготовки педагога будьякої кваліфікації.

Особливе значення підготовка до формування толерантності дітей має для педагогів дошкільної освіти. У дошкільному дитинстві ефективне педагогічне керівництво процесом формування толерантності в дітей надзвичайно важливе, оскільки саме цей період $€$ сензитивним для розвитку особистості дитини, саме в цьому віці формуються особистісні механізми поведінки, формується самосвідомість у формі адекватної оцінки власних 
особистісних якостей, відбувається засвоєння норм та форм поведінки, засвоєння цінностей.

Сучасні тенденції професійної підготовки майбутніх педагогів досліджують як вітчизняні науковці (І. Бех, О. Дубовик, О. Сухомлинська), так і зарубіжні (П. Вебер, О. Джуринський, В. Містер). Культурознавчі аспекти підготовки майбутніх учителів розглядають О. Волошина, І. Зязюн, М. Лещенко, О. Рудницька. У працях В. Бондаря, В. Свдокимова, Н. Кузьміної, В. Лозової, О. Мороза, В. Сластьоніна, В. Семиченко, Г. Троцко та інших розкрито шляхи підвищення ефективності реального педагогічного процесу за умов забезпечення його цілісності, що має значення для розв'язання складного комплексу проблем безпосередньої педагогічної підготовки вихователів в умовах вищого педагогічного навчального закладу.

Виходячи 3 досліджень значення системи освіти у формуванні толерантності (Р. Безюлєва, С. Бондирева, Р. Шеламова, О. Клєпцова, Н. Асташова) ми розглядаємо діяльність дошкільного навчального закладу як важливий чинник формування нових відносин і норм поведінки, зокрема, формування толерантної свідомості та поведінки в дітей старшого дошкільного віку. Спираючись на дослідження в галузі соціалізації людини (А. Мудрик, С. Козлова), виявлено можливості дошкільного навчального закладу як соціалізуючого середовища, визначено його виховний потенціал для пошуку шляхів i способів використання і посилення позитивних впливів на дитину і нівелювання, корекції, компенсації негативних впливів; обгрунтовано можливість і необхідність формування толерантності в контексті соціалізації дошкільника.

У дослідженнях у галузі дитячої психології (А. Реан, Е. Прокоф'єв, Д. Ельконін, Е. Рибалко, С. Розум, М. Осоріна) старший дошкільний вік розглядається як сензитивний для формування толерантності, оскільки. це період формування емоційної сфери дитини, розвитку емпатії, довільної поведінки, засвоєння моральних норм. Праці зарубіжних та вітчизняних психологів (Г. Бреслав, О. Кононко, М. Пірен, В. Хотинець та інші), присвячені розкриттю психологічних особливостей дошкільників, особливо ментальних, закономірностей розвитку мотиваційно-ціннісної, когнітивної їх сфери; доробки педагогів (В. Бойко, О. Вишневський, І. Газіна, О. Лещенко, М. Стельмахович, В. Якубенко та інші), у яких визначено зміст національного виховання дітей.

Разом $з$ тим, аналіз проведених досліджень свідчить про те, що процес підготовки майбутніх вихователів до формування толерантності в дітей старшого дошкільного віку ще не отримав належного наукового обгрунтування. Незважаючи на соціальне замовлення суспільства, доведену сензитивність дошкільного віку до засвоєння цінностей, потребу педагогічної практики в оволодінні технологіями формування толерантності у старших дошкільнят, теоретичних досліджень із проблеми підготовки вихователів до формування толерантності в дітей старшого дошкільного віку явно недостатньо. Відсутні дослідження, у яких було б представлено цілісну концепцію професійної підготовки вихователів до формування толерантності старших дошкільників.

Mema cmammi: розкрити концептуальні основи підготовки майбутніх вихователів до формування толерантності в дітей старшого дошкільного віку, а саме: сутність цієї підготовки, провідну ідею та базові положення, які визначають іiі особливості, систему закономірностей i принципів, на яких будується педагогічний процес та досягається поставлена мета.

Протягом тривалого часу в науці та освітній практиці склалося уявлення про толерантність як суспільну норму та цінність. Прогресивні філософи та педагоги минулого та сьогодення висловлювали різноманітні погляди та описували власний досвід виховання 
толерантності в дітей. У науці сформувався певний напрямок - «педагогіка толерантності», представники якого описували можливості дорослого впливати на формування толерантності дітей різними засобами. У результаті аналізу цих наукових поглядів і підходів, осмислення широкого кола досліджень філософського, соціологічного, педагогічного i психологічного спрямування, що стосуються проблем толерантності, обгрунтування можливості і необхідності формування толерантності в дітей старшого дошкільного віку та специфіки іiі формування саме в цьому віці; висвітлення ролі толерантності в соціалізації дитини дошкільного віку, а також багатого історичного досвіду національного виховання й досвіду виховання інших країн нами визначені базові положення концепції, які було покладено в основу започаткованого нами дослідження.

1. Проблема підготовки студентів педагогічних ВНЗ до формування в дітей старшого дошкільного віку толерантності розглядається в контексті оновлення навчально-виховного процесу у вищий школі, формування готовності до взаємодії з дошкільнятами в середовищі дошкільного закладу. Основні положення дослідження грунтуються на антропоцентричному розумінні взаємодії вихователя з дитиною.

2. Теоретико-методологічну основу дослідження становлять концептуальні положення: про цілісність, взаємозв'язок і зумовленість усіх елементів людської культури; особистість як суб'єкт діяльності, іiі соціальну і творчу сутність; етнічну й культурну зумовленість освіти як соціокультурного феномена.

3. Дошкільна освіта нерозривно пов'язана з соціальними процесами і культурою суспільства, потребує переосмислення, корекції своїх позицій у питаннях виховання толерантної культури. Виховання основ толерантної культури необхідно починати у старшому дошкільному віці, оскільки саме цей вік $є$ сензитивним для формування та розвитку багатьох моральних якостей, у першу чергу- толерантності. Під засадами толерантної культури дитини старшого дошкільного віку розуміємо загальнолюдську цінність, яка відображатиме моральну основу поведінки дітей у суспільстві, спілкування і взаємодії з людьми різних національностей і культурних груп.

4. Результатом виховання основ толерантної культури в дітей старшого дошкільного віку $є$ становлення толерантної особистості дитини, здатної до гуманної взаємодії 3 навколишнім світом і самим собою, що володіє терпимим ставленням, повагою і правовим розумінням оточуючих людей, незалежно від їх національної належності, культурних, релігійних переконань, поглядів і звичок.

5. Показниками толерантності дитини є відкритість та діалогічність.

Відкритість неодмінно передбачає певну внутрішню пластичність суб'єкта спілкування, його здатність, сприймаючи проблеми інших, водночас залишатися самим собою, зберігати й поновлювати гармонію між власним «Я» та іншими людьми. Така внутрішня пластичність потрібна особі, аби не закостеніти в шкаралупі власного «Я» i, разом 3 тим, не зламатися під зовнішнім тиском. «Незламним переконанням» монолітного суб'єктаегоцентрика вона протиставляє голос совісті, що поєднує відкритість із принциповістю, вірність власним духовним цінностям - 3 чутливістю і готовністю відгукнутися на те, що діється навкруги. По суті, розглядувана властивість є однією з морально-екзистенційних основ інтелігентності: саме вона надає змогу суб'єктові поставати свідомим виразником тих або інших соціальних прагнень, масових потреб, водночас репрезентуючи в суспільній свідомості позиції совісті й загальнолюдських моральних цінностей.

Моральне прийняття інших «Я» або будь-яких чинників буття до власної суб'єктивності зовсім не означає підміни їі ними або розчинення в них. Відчувати чужі 
потреби як власні можна лише доти, доки не втрачені відчуття і свідомість «власного» як такого: зрештою йдеться про моральне розширення людського «Я», а не про його розпад.

Феномен відкритості в повноті своїх екзистенційних вимірів відіграє винятково важливу роль як у цілісній організації людського буття, так і у специфічних, усталених у сучасному суспільстві формах спілкування та комунікації, а також у найрізноманітніших галузях духовної культури й творчості. У будь-яких своїх виявах він привчає бачити й поважати невичерпність і неповторність кожного явища буття, невичерпність і унікальність кожної людської особистості, що є обов'язковою передумовою справжньої моральності.

Поряд з відкритістю суттєвою характеристикою толерантності суб'єкта спілкування є діалогізм, або діалогічність.

Розуміння готовності до спілкування принцип діалогічності доповнює суттєвим нюансом: можна сказати, що коли відкритість позначає екзистенційний аспект цієї готовності, то діалогічність як така- аспект смисловий, мовно-мисленнєвий. Власне, діалогічність, діалогізм можна визначити як здатність суб'єкта сприймати і враховувати правомірність, внутрішню обгрунтованість не лише власної думки, а й інших способів міркування і висловлювань, що їх утілюють. Діалогічний суб'єкт «чує» не тільки себе, він уходить у послідовність мислення свого партнера по спілкуванню, зважає на його підстави, його внутрішню логіку й цим радикально відрізняється від суб'єкта монологічного, для якого існує лише одна логіка, один смисл, один «голос»- його власний.

6. В основу концепції покладено ідею толерантної культури особистісної взаємодії вихователя з дітьми як певного стану готовності до організації освітньо-виховної роботи в дошкільних установах. Толерантна культура особистісної взаємодії як складник професійнопедагогічної компетентності вихователя забезпечує успішність взаємодії з дошкільнятами, трансляцію власного світу цінностей у їхню спільноту шляхом діалогічного та полілогічного спілкування. Толерантна культура особистісної взаємодії є інтегрованою єдністю мети, принципів, структурних компонентів, функцій, механізмів ії розвитку у процесі опанування майбутніми вихователями змістом дисциплін психолого-педагогічного та гуманітарного циклів та під час позааудиторної роботи.

7. Формування толерантної свідомості й поведінки в дітей можливе лише за умови розуміння і прийняття ідей i настанов толерантності дорослими. Тому насамперед їх необхідно сформувати у вихователів.

8. Модель підготовки студентів до виховання толерантності в дітей повинна будуватися на основі провідних ідей компетентнісного, системно - діяльнісного та ціннісносинергетичного підходів. Вона має синтезувати єдність цільового, що включає три групи цілей (формування єдності установок на виховання толерантності та реалізацію майбутнім педагогом принципів толерантності в особистій і професійній сферах; формування педагогічної толерантності як фахової компетентності; формування системи знань, умінь, навичок, якостей, необхідних для організації виховання толерантності в дошкільнят); змістового (теоретичний, методичний, практичний, психологічний аспекти підготовки, змістовний потенціал суспільнознавчих і психолого-педагогічних дисциплін, курсів за вибором, варіативних завдань у період практики, науково-дослідної роботи студентів, позааудиторної діяльності); організаційного (нормативна та варіативна частина підготовки, умовне виокремлення етапів підготовки, педагогічно обгрунтоване застосування системи традиційних, активних і евристичних методів і форм навчання студентів, толерантна взаємодія суб'єктів підготовки, реалізація організаційно-педагогічних умов підготовки); результативного (вивчення ефективності підготовки майбутніх педагогів до виховання

Педагогіка вищої та середної школи. - 2015. - Вип. 45 
толерантності в дітей старшого дошкільного віку) компонентів.

Процес підготовки студентів до формування толерантності в дітей старшого дошкільного віку має спиратись на сукупність принципів - науковості, систематичності, інтеграції, діяльнісного підходу, єдності громадянської свідомості й національної самобутності педагогічної діяльності, виховання в умовах специфіки життя і праці відповідно до національного ідеалу, індивідуального й диференційованого підходу до майбутніх педагогів у процесі навчання.

Отже, процес формування професійно-педагогічної компетентності майбутніх вихователів та готовності їх до виховання толерантності в дітей старшого дошкільного віку буде успішним за умов:

- формування толерантної культури як інтегральної характеристики фахівця, компоненти якої взаємопов'язані, взаємозумовлені i тісно взаємодіють у процесі гуманітарної, загальнокультурної та професійної підготовки педагога;

- забезпечення єдності змістовного, діяльнісного й особистісного компонентів освітньо-виховного процесу відповідно до критеріїв сформованості толерантності майбутніх педагогів;

- узгодження соціально й особистісно значущих цілей і цінностей професійної педагогічної освіти;

- інтеграції викладання наук, поєднання інноваційних і традиційних форм проведення занять, забезпечення наступності пізнавальної та практичної діяльності студентів;

- забезпечення кожному студенту можливості повної індивідуальної самореалізації в навчальному процесі;

- ураховування результатів педагогічного моніторингу сформованості у студентів готовності до формування толерантності в дітей дошкільного віку.

Основними компонентами толерантної культури є: 1) мотиваційно - ціннісний, що сприяє прийняттю толерантною культури як цінності, необхідної для взаємодії з іншими людьми; 2) когнітивний, що допомагає придбанню знань про способи спілкування i поведінки в різних життєвих ситуаціях; 3) емоційно-вольовий, що визначає розвиток самовладання, витримки у спірних, конфліктних обставинах; поведінкового, що забезпечує вияв терпимості, доброзичливості, милосердя стосовно людей різних національностей i культур.

Означений концептуальний підхід потребує подальшого підвищення рівня підготовки майбутніх педагогів формування толерантності в дітей, інтеграції виокремленої системи до змісту психолого-педагогічних дисциплін фахової підготовки майбутніх вихователів у вищих педагогічних навчальних закладах.

\section{Література}

1. Ильинская Е. А. Формирование толерантности у детей старшего дошкольного возраста средствами социально-культурной деятельности: автореф. дис. на соискание ученой степени канд. пед. наук: спец. 13.00 .05 «Теория, методика и организация социальнокультурной деятельности»/ $\quad$ Е. А. Ильинская. - Санкт-Петербург, 2009. $\quad 36$ c. 2. Безюлева Г. В. Толерантность: взгляд, поиск, решение / Г. В. Безюлева, Г. М. Шеламова. Москва : Вербум, 2003. - 168 с. 3. Поніманська Т. І. Підготовка педагогічних кадрів для системи дошкільної освіти / Т. І. Поніманська. - Київ : Либідь, 2004. - 456 с. 4. Радчук Г. К. Аксіопсихологія вищої школи: [монографія]/ Г. К. Радчук. - Тернопіль: ТНПУ ім. В. Гнатюка, 2014. - 380 с. 5. Слепцова И. Ф. Формирование готовности будущих 
воспитателей к взаимодействию $\mathrm{c}$ детьми дошкольного возраста в процессе профессиональной подготовки: автореф. дис. на соискание ученой степени канд. пед. наук: спец. 13.00.08 «Теория и методика профессионального образования»/ И. Ф. Слепцова. Москва, 2007. - 24 с. 6. Тодорцева Ю. В. Формування толерантності майбутніх учителів у процесі професійної підготовки: автореф. дис. на здобуття наук. ступеня канд. пед. наук: спец. 13.00.04 «Теорія і методика професійноїосвіти»/ Ю. В. Тодорцева. - Одеса, 2004. $20 \mathrm{c}$.

УДК 37.091.313:[796+811.111]

Людмила Кадченко, Валентина Марчик

\section{ПРЕДМЕТНА ІНТЕГРАЦІЯ ФІЗКУЛЬТУРИ Й АНГЛІЙСЬКОЇ МОВИ ЯК ЗАСІБ ЗБАГАЧЕННЯ ЗМІСТУ СУЧАСНОГО УРОКУ}

Кадченко Л. П., Марчик В. І. Предметна інтеграція фізкультури й англійської мови як засіб збагачення змісту сучасного уроку.

Стаття присвячена проблемі інтегрованого підходу в навчанні. Розглядається можливість гармонійного поєднання фізичної культури з іноземною мовою. Обгрунтовується доцільність проведення інтегрованих уроків фізкультури й англійської мови, визначаються шляхи реалізації інтегрованого підходу під час організації спортивно-оздоровчих заходів чи уроків фізкультури іноземною мовою.

Ключові слова: предметна інтеграція, інтегрований підхід, інтегроване навчання, фізкультхвилинка, команда.

Кадченко Л. П., Марчик В. И.Предметная интеграция физкультуры и английского языка как средство обогащения содержания современного урока.

Статья посвящена проблеме интегрированного подхода в обучении. Рассматривается возможность гармоничного сочетания физической культуры с иностранным языком. Обосновывается целесообразность проведения интегрированных уроков физкультуры и английского языка, определяются пути реализации интегрированного подхода при организации спортивно-оздоровительных мероприятий и уроков физкультуры на иностранном языке.

Ключевые слова: предметная интеграция, интегрированный подход, интегрированное обучение, физкультминутка, команда.

Kadchenko L. P., Marchyk V. I. Subject integration of physical education and English as a means of enriching modern lesson content.

The article deals with an integrated approach in teaching. The possibility of a harmonious combination of physical culture and foreign language is examined. The reasonability of conducting the integrated lessons of physical culture and English and the ways of implementation of an integrated approach in the organization of sports activities and physical education lessons in a foreign language are substantiated.

Key words: subject integration, integrated approach, integrated learning, physical activity break, command.

Інтеграція - це вищий рівень реалізації завдань освіти. В освітній діяльності інтегрований підхід набуває все більшого поширення, оскільки завдяки йому традиційні 